\title{
MANAGERIAL PUBLIC ADMINISTRATION: STRATEGY AND STRUCTURE FOR A NEW STATE
}

\author{
Luiz Carlos Bresser-Pereira \\ Journal of Post Keynesian Economics, 20 (1), \\ 1997: 7-23.
}

In the 1980s, following the breakup of the international debt crisis, the theme that caught the attention of politicians and policy makers all over the world was structural adjustment, or, in more analytical terms, fiscal adjustment and marketoriented reforms. In the 1990s, although structural adjustment remains a major objective, the emphasis has changed to the reform of the state, and particularly to administrative reform. The central question now is how to rebuild the state-how to redefine a new state in a global world.

This change of focus also occurred in Brazil. One of the major reforms to which the Cardoso administration is committed is the administrative reform. In the 1994 presidential campaign this was not an issue, yet the president decided to transform the old bureaucratic secretary of the presidency that managed civil service into a new Ministry of Federal Administration and State Reform. Chosen as minister, I proposed to add administrative reform to the constitutional reforms that had already been defined as a priority by the new government - the tax reform, the social security reform, and the elimination of state monopolies. The immediate reaction of civil servants, intellectuals, and the media was strongly negative. They reacted against change, to a reform that could be threatening. Yet, after a few months, supports popped up, coming from state governors, from mayors, businesspeople, the press - which changed its attitude - and finally from public opinion. Suddenly administrative reform had become a crucial reform, demanded not only internally but also by foreign investors and multilateral financial agencies. The constitutional amendment was widely debated and sent to Congress in August 1995. The amendment was followed by the publication of a 1995 white paper on the administrative reform - Plano Diretor da Reforma do Aparelho do Estado - whose 
basic proposal is to transform Brazilian public administration from a bureaucratic administration into a managerial one. The substitution of a managerial for a bureaucratic public administration turned into a national issue.

Why this new interest in the reform of the state and particularly of the state apparatus? What is the content of this reforms? Are they part of the neoliberal ideology, or a necessary course to managing a contemporary capitalist state? What is the relationship between the managerial strategy and the structure of the new state emerging out of its great crisis - the crisis of the 1980s that in many ways extended into the 1990s? These are some questions that I will try to answer here, though I am well aware that they are limited and provisory answers.

\section{Reform of the State as a Major Concern}

We may cite many reasons for the increasing interest in state reform in the 1990s. The basic one is probably that people realized that structural adjustment was not enough. Since the mid-1980s the highly indebted countries engaged in fiscal adjustment, trade liberalization, privatization, and deregulation. Outcomes were positive, to the extent that the acute features of the crisis were overcome: Balances of payments came back to relative control, inflation rates fell everywhere, countries recovered some creditworthiness. But growth did not resume. The neoliberal assumption behind the reforms - the assumption that the ideal was the minimal state, only committed to guaranteeing property rights, leaving the full coordination of the economy to the market - proved unrealistic. First, because, regardless of the ideological dominance achieved by the neoconservative credo, in no countrydeveloping or developed - is there political legitimacy for such a minimal state. There is not even political support for a state that only adds to its role provision of education, health care, and compensatory social policies. People demand more from the state. Second, it soon became apparent that the assumption that state failures are necessarily worse than market failures was just a form of dogmatic reasoning. The limitations of state intervention are self-evident, but their strategic role in contemporary capitalism is so great that they cannot be ignored or eliminated, as neoliberal thinking assumes. As Przeworski (1996, p. 4) observes, the neoliberal view, popular in the 1980s, that "even in the absence of 'traditional' failures, markets are efficient now appears dead, or at least moribund."

On the other hand, it became increasingly clear that the basic cause of the great crisis of the $1980 \mathrm{~s}$ - a crisis that only the east and southeast Asian countries were 
able to avoid - is a crisis of the state: a fiscal crisis of the state, a crisis of the mode of state intervention, and a crisis of the bureaucratic form by which the state is managed. Well, if the proposal of a minimum state is not realistic, and if the basic factor behind the economic crisis is the crisis of the state, there is only one possible conclusion: The solution is not to wither with the state, but to rebuild it, to reform it. The reform will probably mean shrinking the state to limit its role as a producer of goods and services, and to a lesser extent, as a regulator; but it will probably entail increasing its role in financing public nonstate organizations that will respond competitively for the provision of the social services where externalities or basic human rights are involved, and increasing its role in promoting international competitiveness for local industries.

Reform of the state is a broad subject. It involves political aspects - those related to promoting governability - and economic and administrative aspects - those leading to improved governance. Among the reforms aimed at increasing governance - the effective capacity the government has to realize its policies - the economic reforms that reduce the public debt and promote public savings, particularly fiscal adjustment and privatization, are the major reforms, Yet recently, administrative reforms - reforms directly guided toward the reform of the civil service, making it more consistent with contemporary capitalism- have begun to receive increasing attention. Why?

There is a simple explanation: People are becoming increasingly aware that bureaucratic public administration is inconsistent with the demands that civil society has in contemporary capitalism in relation to governments. People demand much more from the state than it can deliver. And the immediate reason for that gap is not only fiscal, as O'Connor (1973) pointed out, nor just political, as Huntington (1968) stressed. It is also administrative. Economic and political resources are by definition scarce, but this limitation may be partially overcome by efficient use by the state. When one cannot count on the market - that is, when resource allocation through the market is not a feasible solution, given its distorted character or

\footnotetext{
I extensively discuss this theme in Bresser-Pereira (1988, 1996a), and BresserPereira, Maravall and Przeworski (1993).

${ }^{2}$ For a recent discussion of governability and demands on the state, see Diniz (1995).
} 
incompleteness, the role of a proficient public administration becomes strategic in reducing the gap between social demands and their fulfillment. ${ }^{3}$

There is, however, a broader reason for the interest in reforming the state and particularly public administration: the increasing relevance of protecting the public patrimony (res publica) against the threats of its "privatization," or, in other words, against rent-seeking activities. The protection of the state as long as it embodies the res publica corresponds to a basic right that finally in the fourth quarter of this century started to be defined - a right that could be called "public rights." In the eighteenth century, the illuminist philosophers and the British courts defined the civil rights that were introduced in the next century by the liberal (in the European sense) politicians in the constitutions of all civilized countries. In the nineteenth century, the political rights, particularly the universal suffrage, were defined and implemented in most countries by the democrats. In this same century the socialist defined the social rights that were introduced in the first half of this century in the constitutions of all countries by the social-democrat political parties.

Yet the emergence of the welfare state to enforce social rights and the increasing role the state assumed in promoting economic growth and international competitiveness in this century implied an immense increase in the state as res publica. And so implied a substantial increase in the greed of individual and groups in submitting the state to their special interests. The privatization of the tax burden (the main form of the res publica) was now the main objective of rent seekers.

If the historical realization of the relevance of protecting the individual against an oligarchic state look place in the eighteenth century, and of assuring the democratic rights of political participation and of protecting the poor and the weak against the rich and the powerful in the nineteenth, the importance of protecting the public patrimony only became dominant in the second half of this century. It is not by accident that, almost simultaneously, a Brazilian social-democratic political scientist for the first time wrote about the "privatization of the state" (Martins, 1978) and a conservative American economist (Krueger, 1974) defined "rent seeking." They were referring to the same problem. They were acknowledging that it was necessary to protect the res publica from the greed of powerful individuals and groups. If, in the eighteenth century, civil rights and, in the nineteenth century,

\footnotetext{
${ }^{3}$ See the recent contributions of Stiglitz (1995) and Przeworski (1995).

${ }^{4}$ T.H. Marshall (1950) wrote the classic essay on this subject.
} 
political and social rights were defined, it was now necessary to define a forth and basic right - the public rights: the right that all citizens have that what is meant to be public will be indeed public. Or, in other words, the right that what is state property is public - that is, of and for everybody, instead of being appropriated by a few.

The state is meant to be public, public nonstate organizations (or nongovernmental organizations) are meant to be public. Strictly public goods, as a protected environment, are meant to be public. Public rights are the rights we have that the public patrimony, that the res publica, understood in a broad sense, be public _ of and for everybody_instead of the object of rent seeking, instead of being privatized.

When the protection of public rights started to become a dominant concern in the world, it became increasingly clear that the republic had to be refounded, that the reform of the state gained a new priority, that democracy and bureaucratic public administration - the two institutions created to protect the public patrimonyshould be changed: Democracy should be improved and made more participative or more direct, and bureaucratic public administration should be replaced by a managerial public administration.

\section{Patrimonialism and bureaucracy}

Privatizing the state, or mixing the private and the public patrimony, was the defining characteristic of governments in precapitalist and predemocratic societies. Patrimonialism meant the inability or reluctance of the prince to distinguish the public patrimony from his private possessions. Administration of the precapitalist state was a patrimonialist administration. The rise of capitalism and democracy brought with it a clear distinction between res publica and private possession. Democracy and bureaucratic public administration emerged as the main institutions aimed at protecting the public patrimony against the privatization of the state. Democracy is the political device that guarantees civil rights against tyranny, that asserts the political rights of electing and being elected, that assures social rights against exploitation and affirms the public rights in relation to the public patrimony. Bureaucracy is the administrative institution that uses as instruments to

\footnotetext{
5 Note that the concept of "privatization of the state" or of "privatization of the public patrimony" should not be confused with the privatization of state-owned enterprises - the sale of part of the public patrimony to private owners. Privatization in this sense is a regular sale - not a vicious private appropriation - of an asset that society concludes should be in private, not in public, hands.
} 
fight nepotism and corruption-two inherent traces of patrimonialist administration - the principles of a professional civil service and an impersonal, formal, legal, and rational administrative system.

The emergence in the nineteenth century of a bureaucratic public administration to replace the patrimonialist forms of administering the state represented great progress. Its main analyst - Weber (1922) - was quite vigorous in pointing out the superiority of rational-legal authority over patrimonialist power. Yet, when, in the twentieth century, the state increased its social and economic role, the basic strategy adopted by bureaucratic public administration-the hierarchical and formalistic or legal control of procedures-proved inappropriate. This strategy could be effective in avoiding corruption and nepotism, but it was slow, expensive, inefficient. It could make sense in the times of the eighteenth-century liberal state - a small state concerned with the protection of properly rights, a state that only need a parliament to define the laws, a judicial and police system to assure its enforcement, an armed force to protect the country against foreign enemies, and a finance ministry to collect taxes. It did not make sense anymore when the state had added to its role providing public education, public health, public culture, social security, science and technology incentives, infrastructure investments, environment protection. Now, instead of three or four ministries, fifteen or twenty were required. Instead of the tax burden representing 5 to 10 percent of GDP, it now represents 30 to 60 percent of GDP. Instead of the old bureaucratic public administration, a new form of administration emerged - a managerial public administration - that borrowed the huge practical and theoretical advances the management of business enterprises underwent in the twentieth century without losing its specific characteristic as a public administration: an administration that is not profit-oriented but oriented to the public interest.

The new public administration cannot limit itself to effectively avoiding nepotism and corruption, it has to be efficient in providing public and semi-public goods that the state was committed to produce directly or to finance indirectly. If, in the developed countries, individual (civil and political) and social rights were reasonably protected, public rights were not: the res publica was the object of all sorts of threats. It is true that sheer nepotism and corruption were moderate, but new forms of privately appropriating the public patrimony emerged. Businesspeople obtained unnecessary subsidies and lax renunciations, the middle 
class secured special entitlements that it is not ready to admit, the civil servants were often working inefficiently or just not working - when redundancies prevailed - while they were protected by strict tenure laws.

In the developing countries - where in this century a developmentalist state replaced the welfare state - the situation was much worse: Individual and social rights often remained unprotected, nepotism and corruption thrived with bureaucracy, which was marked by privileges and redundancies. While, in the nineteenth-century liberal state, bureaucratic public administration was a device to assure property rights, assuring the appropriation of the economic surplus by the emerging capitalist class, bureaucratic administration in the developmentalist state was a form of surplus appropriation by a new middle class of bureaucrats or technobureaucrats. In the liberal state, the price of entrepreneurship was the concentration of income in the hands of the bourgeoisie through market mechanisms; in the developmentalist state, economic surplus was shared by the capitalist and the bureaucratic class, which used, besides the market mechanism, the political control of the state to enrich themselves. If the res publica was not well protected by bureaucratic administration in the developed countries, given its inefficiency in administering the welfare state, it was still less protected in the developing countries where the bureaucratic class was engaged not only in building the state but also in partially replacing the bourgeoisie in the capital accumulation process and in the private appropriation of the economic surplus.

\section{Managerial public administration}

Managerial public administration emerged in the second half of this century as an answer to the crisis of the state, as a form of coping with the fiscal crisis, as a strategy of making the administration of the huge services the state took on less expensive and more efficient, and as a device to protect the public patrimony against rent seeking or sheer corruption. More specifically, since the $1960 \mathrm{~s}$ or at

\footnotetext{
${ }^{6}$ I developed the idea of the emergence of a bureaucratic or technobureaucratic class in two books published in Brazil in the 1970s. In A Sociedade Estatal e a Tecnoburocracia (1980), I collected my general or theoretical essays on the subject; in Estado e Subdesenvolvimento Industrializado (1977), I concentrated on the role of this new class in association with the capitalist class in running the developing countries where bureaucratic-capitalist regimes had emerged.
} 
least the early 1970s, a widespread dissatisfaction with bureaucratic public administration developed.

Some basic characteristics define managerial public administration: It is outcome- and citizen-oriented; it assumes that politicians and civil servants are entitled to a limited degree of trust; it uses as strategy decentralization and the incentive to creativity and innovation; it controls public managers through the device of management contracts.

While bureaucratic public administration is process-oriented, strictly defining legal procedures to hire personnel, to purchase goods and service, and to satisfy citizens' demands, managerial public administration is result-oriented. Bureaucracy concentrates itself in processes, notwithstanding the high inefficiency involved, because it believes that this is the safer way to avoid nepotism and corruption. Controls are preventive; they come a priori. Besides the bureaucracy realizes that to punish deviations is often difficult, if not impossible; thus, it prefers to prevent them through strict legal means. Finally, since it lacks clear objectives-an extremely difficult task is to define performance indicators for state agenciesbureaucracy has no alternative but to control legal procedures. In contrast, managerial public administration assumes that nepotism and corruption are to be fought, but that this does not require rigid procedures. They might have been necessary when patrimonialist values were dominant, but not now, when the mixing of private and public patrimony is universally rebuked. On the other hand, new forms of privately appropriating the res publica have emerged that are not prevented by bureaucratic methods. Rent seeking is usually a more subtle and sophisticated way of privatizing the state, demanding new counterstrategies. Managerial administration, decentralization, the delegation of authority and responsibility to public managers, the strict control of the achievement of the agreed-upon performance indicators, is not only a much more efficient way of managing the state, it is also more effective in fighting these new forms of state privatization.

While bureaucratic public administration is self-referential, managerial public administration is oriented toward citizens. As Barzelay observes (1992, p. 8), "a bureaucratic agency is focused on its own needs and perspectives; a customerdriven agency is focused on customer needs and perspectives." Modern bureaucracy arose in the nineteenth century in a moment when the power of the

${ }^{7}$ As Ostrom (1973, p. 15) says in The Intellectual Crisis in American Public Administration, "the sense of crisis that has pervaded the field of public administration over the last generation has been evoked by the insufficiency of the paradigm inherent in the traditional theory of public administration." 
state still had to be affirmed against feudal or regional powers. Actually, the rise of the national state took place in Europe through the absolute monarchies, where a patrimonialist bureaucracy played a central role. Modern capitalist bureaucracies are an evolutionary outgrowth of patrimonialist bureaucracy that became distinguished by clearly discriminating the public from the private patrimony, but have remained very close to their ancestors where affirming the power of the state was concerned. That is why bureaucracies tend to be self-oriented. Besides promoting their own interests, they are primarily interested in securing that the power of the state - the "extroverse power" over citizens - be asserted. In contrast, managerial public administration assumes that this power is no longer being seriously challenged in the developed and semideveloped countries. ${ }^{9}$ Thus, civil service should not be self-referential but oriented toward the service of citizens. After all, civil service is a public service; it is a service to the public, to the citizen.

In order to control outcomes in a decentralized way, bureaucratic public administration requires a certain degree of trust in politicians and public officialsa limited trust, a confidence that is continuously being checked by the control of results, but in any case a confidence that allows for delegation, for the possibility of assuring the public manager the freedom to choose the more appropriate means to achieve the pre-established goals, instead of defining them and the respective procedures in the law. This confidence does not exist in bureaucratic administration. And it is unacceptable to neoconservative or to neoliberal reasoning, given its radically pessimistic view of human nature. Yet, without some degree of trust it is impossible to secure cooperation, and if administration is a form of control, it is also a form of cooperation. the radical pessimism of neoliberais is functional to validate their conclusion about the minimal state, but it makes no sense when the minimal state is just an unrealistic mental construction, while the modern state is a reality that must be efficient and effectively managed.

\footnotetext{
${ }^{8}$ Note that the nation-state or country encompasses the state and civil society. The state is the unique organization that holds extroverse power-the power of imposing law and taxes over civil society, that is, over a structured group of citizens that are not a direct part of the state, but are simultaneously the object of state power and the source of government legitimacy.

9 Except by illegal activities or associations, such as the mafia. In the developing countries, there is also a threat posed by several types of fundamentalism.
} 


\section{Neoliberal reform?}

The managerial approach to public administration emerged with strength in Britain after the conservative Thatcher government took power in 1979, leading some interpreters to view this approach as intrinsically conservative. Actually, it was only in Britain that managerialism took over civil service at that time, leading to a profound and successful administrative reform. A series of programs - the "Efficiency Units" program, with the scrutiny reports, the "Next Step" program with the executive agencies, and the "Citizens Charter" program-were able to produce more flexible, decentralized, efficient, and citizen-oriented civil service in Britain. The traditional civil service in Britain was deeply transformed; it lost its bureaucratic features and gained managerial ones. ${ }^{10}$ Yet similar reforms look place in New Zealand, Australia, and Sweden, where social-democratic parties in office most of the time. in the United States, Osborne and Gaebler (1992), who coined the term "reinventing government" in an influential book on the subject, described administrative reforms that had been taking place since the early 1970s; they did not, however, originate in federal government, but in municipal and state administrations. The goal of transforming federal public administration according to the managerial approach took place in 1992, when a Democratic politicianPresident Bill Clinton - transformed the idea of reinventing government into a government program: the "National Performance Review." In France, reforms in the same direction started in 1989 , when a social-democratic prime minister, Michel Roccard, was in office. In Brazil, the first attempt in the direction of a managerial administration dates from 1967-long before neoliberal ideas carne out, benefiting from the crisis of the state.

\footnotetext{
${ }^{10}$ The best analysis of the British experience I know was written by a sociologist from the University of Warwick, commissioned by British trade unions. Fairbrother (1994) wrote a moderately critical analysis. See also Tomkins (1987), Nunberg (1995), and Plowden (1994). For a radically critical approach, see Pollitt (1990).

For an evaluation of this program, see Ketl (1994) and Ketl and Dilulio (1994, 1995), who compare Clinton and Gore's reinventing government program with the Republican "Contract with America," which they label an "erasing government" program - a truly neoconservative, cut-back management program.

The reform was launched in the Castelo Branco administration, through the Decreto-Lei 200, which allowed for radical decentralization of Brazilian public administration, including state-owned enterprises. See Beltrão (1984), Martins (1995). Hélio Beltrão was involved in the reform, in 1967, and later, in 1998, became minister of federal administration, launching a debureaucratization program. Yet, after the transition to democracy in 1985, the reform was abandoned. The new democratic government unsuccessfully attempted to restore a full bureaucratic system.
} 
Managerial public administration is seldom identified with neoliberal views for another reason. Managerial techniques were often introduced simultaneously with structural adjustment programs aiming to cope with the fiscal crisis of the state. As Nunberg (1995, p. 11) observes, "the first reform phase, commonly called 'cutback management,' consisted of measures to curb public spending and civil service staff in response to fiscal constraints." This was true in Britain, Canada, Australia, New Zealand, Japan, and the United States. It is presently true in Latin America, including Brazil, where an administrative reform is formally oriented to substitute managerial for bureaucratic public administration, but where spending cuts are an essential part of the program. ${ }^{13}$ This fact usually provokes strong reactions from civil service, besides leading the bureaucratic left to make charges of neoliberalism. As an indignant British civil servant once said, "more efficient really means cheaper" (Plowden, 1994, p. 4).

Mixing fiscal adjustment with conservatism or neoliberalism may have a historical explanation, but not a logical one. Neoliberalism arose as a reaction against the fiscal crisis of the state and so became identified with spending cuts, downsizing the state. But it soon became clear to social-democratic administrations that fiscal adjustment was not an ideological proposal, but a necessary condition for any strong and effective government. This fact, plus the obvious superiority of managerial over bureaucratic public administration, led governments of all ideological tendencies to get involved in administrative reforms, that usually have a twofold orientation: expenditure reduction in the short run, increased efficiency through managerial orientation in the medium rum.

The more serious risk facing this kind of reform is hostility toward civil service and toward the involvement of civil servants. In Britain, where reform went farther, this was and still is the most difficult problem facing the government. the reform was possible for two reasons: because in the late 1970s senior civil servants and major civil service consultants were aware that a reform was badly needed, and because Margaret Thatcher was sanguinely determined to reduce public administration costs. This allowed for a kind of coalition between government and

\footnotetext{
After the failed attempt to restore a bureaucratic system in Brazil in 1995, the reform-oriented Cardoso administration proposed and is implementing an administrative reform according to the managerial approach (Ministry of Federal Administration and State Reform, 1995; Bresser-Pereira, 1995, 1996b).
} 
top civil servants. Yet this coalition was fragile, given the obvious negative altitude Thatcher and associates held toward civil service.

The political reactions against managerial public administration have an obvious ideological origin. Pollitt's (1990) Managerialism and the Public Service is a good example of this. Managerialism is seen as a set of ideas and beliefs that have as major values management itself, the objective of continuously increasing productivity, and the orientation to the consumer. Abrucio (1996), in a survey of managerial public administration, contrasts this "pure managerialism" that be calls the "new public administration," with the "public service oriented" approach sponsored by Pollitt, that intends to be a managerial alternative to the British model. Actually this view is just an attempt to update the old bureaucratic model; it is not a managerial alternative. Opposing consumer orientation (pure managerialism) against citizen orientation (reformed managerialism) makes no sense. A crucial reform program that is being undertaken by the British government is the Citizen Chart. The citizen is also a consumer. Any managerial public administration has to see the individual, in economic terms, as a consumer (or a user) and in political terms, as a citizen.

\section{Reforming state structure}

Managerial public administration, as we have seen, involves a change of management strategy, but this strategy must be put to work in a reformed administrative structure. The general idea is decentralization, delegation of authority. But it is necessary to be more specific, defining clearly the sectors the state operates, the types of ownership, and the kinds of administration that are more suited to each sector.

Any modern slate counts four sectors: the strategic core, exclusive activities, nonexclusive services, and the production of goods and services for the market. The strategic core is where law and policies are defined, and their enforcement is in the last instance assured. It is formed by the parliament, the courts, the presidency, or the prime minister, its ministers, the top civil servants, major local authorities, and the governors and their secretaries when the political system is federal.

As Plowden (1994, p. 10) notes, "the Prime Minister herself repeatedly made clear her view that anyone with talent and enterprise would not be in the civil service, but would be in the private sector making money."

The idea of opposing a consumer orientation, which would be conservative, to a user orientation, which would be social-democratic, makes a little more sense, if we define the consumer as an individual who pays for the services he or she gets from the state, while the user is financed by the state. 
The exclusive activities are the ones that involve state power. They are the activities that directly guarantee that laws and public policies are followed and financed, the armed forces, the police, the tax collection agency-the traditional functions of the state - and also the regulatory agencies, the agencies that finance, foment, and control social services and social security are part of this sector. Thus, the exclusive activities should not be identified with the classical liberal state, where the police and the armed forces are enough.

The nonexclusive services are the services that the state provides, but, because they do not involve the exercise of the state's extroverse power, the private and the public nonstate ("nongovernmental") sectors may also provide them. This sector includes educational, health, cultural, and scientific research services.

Finally, the production of goods and services sector is formed by the state-owned enterprises.

Given these four sectors, three questions must be answered: What type of administration, what kind of ownership, and what kind of institution should prevail in each sector in the new state that is arising in the 1990s? The answer to the first question could be straightforward: Managerial public administration is to be adopted. Yet, a caveat is necessary: In the strategic core, where effectiveness is often more relevant than efficiency, updated bureaucratic characteristics still have a place. An essential strategy in reforming the state apparatus is to strengthen the strategic core, to bestow it with highly competent, well-trained, and well-paid civil servants, with civil servants who share the civil service ethos of serving the citizen. In this area, career and tenure provisions still hold, although they should be seen in a quite more flexible way, when compared with the correspondent terms existing in traditional bureaucratic administration. In the exclusive activities, management is supposed to be decentralized; in the nonexclusive services management will be more than decentralized - it will be autonomous: Civil society will share its control with government.

The ownership question is essential. In the strategic core and in the exclusive state, activities ownership will by definition be stale ownership. In contrast, in the production of goods and services, there is an increasing consensus today that ownership is supposed to be private, particularly when the market is able to control business enterprises. When there is a natural monopoly, the question is not so clear, but even in this case an effective and independent regulatory agency will make private property more suitable. 
In the realm of nonexclusive services, definition of the ownership regime is more complex. If we assume that they are supposed to be financed or fomented by the state, either because they involve basic human rights (education, health), or because they imply sizable externalities (education, health, culture, scientific research), there is no reason to be private. On the other hand, since they do not involve use of state power, there is no reason to be controlled by the state. If they are not supposed to be either under state or under private ownership, the alternative is to adopt public nonstate ownership, or, using Anglo-Saxon terminology, nongovernmental ownership. "Public" in the sense that they are devoted to the public interest, that they are of and for everybody, that they are not profit-oriented; "nonstate" because they are not part of the state apparatus.

In the United States, all universities are public nonstate organizations. They may be called "private" or "state-controlled," but, as a matter of fact, the "private" are not profit-oriented and the "state-controlled" do not have civil servants. They are partially financed or subsidized by the state - the "private" less than the "state controlled"- but they are all independent bodies controlled by boards that represent civil society and - in minority form - the government. In the United Kingdom, universities and hospitals used to be state-controlled: They are no longer; they are now "quasi-nongovernmental organizations" (QUANGOS). They were not privatized: They were changed from state control to public control.

There are three possibilities in terms of nonexclusive services: They may remain state-controlled, they can be privatized, or they may be financed or subsidized by the state but controlled by society, that is, transformed into public nonstate organizations. Bureaucratism and statism sponsor the first alternative; radical neoliberalism opts for the second course; modern social-democracy or socialliberalism (liberal democracy in the American sense) chooses the third way. Managerial public administration is inconsistent with the first alternative, and lives with difficulty with the second; it is perfectly comfortable with the third. Here the state is not viewed as a producer-as it is held by bureaucratism - or as just a regulator that guarantees contracts and property rights - as the neoliberal credo says-but as a "financier" (or "subsidizer") of the nonexclusive services. The subsidy may be given directly to the public nonstate organization, through the budget in Brazil we are calling this institution "social organizations"- or, in a more radical change, it may be given directly to the citizen in the form of vouchers. Yet, 
they will continue to be state-financed, as contemporary society, notwithstanding the neoliberal offensive, bolds that these activities should not be just submitted to market coordination.

Two main institutions will be used to implement this reform: In the realm of the exclusive activities, the idea is to create "executive agencies," while the nonexclusive activities are supposed to be transformed in "social organizations." The executive agencies will be fully part of the state, while the social organizations will be part of the public nonstate sector. They will be nongovernmental organizations that are authorized by the parliament to share the state budget. The tool that the strategic core will use to control the exclusive activities and the nonexclusive services is the management contract. The executive agencies, in the exclusive activities, and the social organizations, in the nonexclusive services will be decentralized. In the agencies, the minister will choose the chief executive officer and will sign the management contract with him or her; in the social organizations the chief executive officer will be chosen by the board; the role of the minister will be to sign the management contracts and to control outcomes. The management contracts will be provide the personnel, material, and financial means for the agency or social organization and will define in very clear, qualitative and quantitative way, the targets and respective performance indicators: the agreedupon outcomes.

\section{Conclusion}

After the great crisis in the 1980s, a new state is being built in the 1990s. This new state will be the outcome of deep reforms-reforms that will enable the state to perform the roles the market is not able to perform. The objective is to build a state that responds to the needs of its citizens, a democratic state where bureaucrats respond to politicians and politicians to the voters in an accountable way. For that, there are essential moves: political reform to increase the legitimacy of governments; fiscal adjustment, privatization, deregulation to reduce the size of the state and improve its financial health; and administrative reform that, in addition to improving the financial situation of the state, will provide the means for good governance. In this paper I have described the features of this last reform-the reform of the state apparatus - a reform that will allow for a managerial public administration in the public sector. 


\section{REFERENCES}

Abrucio, Fernando Luiz, "O Impacto do Modelo Gerencial na Administração Pública: Um Breve Estudo sobre a Experiência Internacional Recente.” Revista do Serviço Público, 1996.

Barzelay, Michael. Breaking through Bureaucracy. Berkeley: University of California Press, 1992.

Beltrao, Hélio. Descentralização e Liberdade. Rio de Janeiro: Record, 1984.

Bresser-Pereira, Luiz Carlos. Estado e Subdesenvolvimento Industrializado. São Paulo: Brasiliense, 1977.

Bresser-Pereira, Luiz Carlos.. A Sociedade Estatal e a Tecnoburocracia, São Paulo: Brasiliense, 1981.

Bresser-Pereira, Luiz Carlos.. "Economic Reforms and the Cycles of the State." World Development, August 1993, 21(8). [Originally presented as a paper to the seminar "Democratizing the Economy," sponsored by the Wilson Center and the University of São Paulo, July 1988; published in Portuguese, 1989.]

Bresser-Pereira, Luiz Carlos.. "A Reforma do Aparelho do Estado e a Constituição de 1988." Revista del Clad: Reforma y Democracia, 1995,4.

Bresser-Pereira, Luiz Carlos..Economic Criyis and the State Reform in Brazil. Boulder, CO: Lynne Rienner, 1996a.

Bresser-Pereira, Luiz Carlos. "Da Administração Pública Burocrática à Gerencial" Revista do Serviço Público, January 1996b, 47(1).

Bresser-Pereira, L.C.; Maravall, J,M.; and Przeworski, A. Economic Reforms in New Democracies. Cambridge: Cambridge University Press, 1993.

Dilulio, Jr., John J. Fine Print: The Contract with America, Devolution, and the Administrative Realities of American Federalism. Washington, DC: Brookings Institution, Center for Public Management, March 1995.

Diniz, Eli. "Governabilidade, Democracia e Reforma do Estado: Os Desafios da Construção de uma Nova Ordem no Brasil dos Anos 90.” Dados, 1995, 38(3).

Fairbrother, Peter. Politics and the State as Employer. London: Mansell, 1994.

Huntington, Samuel P. Political Order in Changing Societies. New Haven: Yale University Press, 1968.

Ketl, Donald F. "Reinventing Government? Appraising the National Performance Review." Washington, DC: Brookings Institution, Center of Public Management, August 1994.

Ketl, D., and Dilulio, J. Inside the Reinvention Machine: Appraising Governmental Reform. Washington, DC: Brookings Institution, Center for Public Management, 1994.

Ketl, D., and Dilulio, J..Cutting Government. Washington, DC: Brookings Institution, Center for Public Management, May 1995.

Krueger, Anne. "The Political Economy of the Rent-seeking Society." American Economic Review, June 1974, 64(3). 
Marshall, T.H. "Citizenship and Social Class." In T.H. Marshall and Tom Botomore (eds.), Citizenship and Social Class. London: Pluto Press, 1992 [originally published in 1950].

Martins, Luciano. “"Estatização' da Economia ou 'Privatização' do Estado.” Ensaios de Opiniao, 1978, 2 (7).

Martins, Luciano.. Reforma da Administração Pública e Cultura Política no Brasil: Uma Visão Geral. Brasilia: Escola Nacional de Administração Pública, Cadernos ENAP no. 8, 1995.

Ministry of Federal Administration and State Reform. Plano Diretor da Reforma do Aparelho do Estado. Brasília: Presidency of the Republic, Imprensa Nacional, November 1995.

Nunberg, Barbara. "Managing the Civil Service-Reform Lessons from Advanced Industrialized Countries." Washington, DC: World Bank Discussion Paper no. 204, April 1995.

O'Connor, James. The Fiscal Crisis of the State. New York: St. Martin's Press, 1973. Osborne, D., and Gaebler, T. Reinventing Government. Reading, MA: Addison-Wesley, 1992.

Ostrom, Vincent. The Intellectual Crisis of American Public Administration. Tuscaloosa: University of Alabama Press, 1973 [2d ed. 1989].

Plowden, William. Ministers and Mandarins. London: Institute for Public Policy Research, 1994.

Pollitt, Christopher. Managerialism and the Public Service. Oxford: Blackwell, 1990 [2d ed. 1993].

Przeworski, Adam. "Reforming the State: Political Accountability and Economic Intervention." Paper presented to the conference "Inequality, the Welfare State and Social Values," El Escorial, Spain, July 1995.

Przeworski, Adam. "On the Design of the State: A Principal-Agent Perspective." Paper presented to the seminary "Reforma do Estado na América Latina e no Caribe," sponsored by the Ministry of Federal Administration and Reform of the State, the Interamerican Development Bank and the United Nations. Brasília, May 16-17, 1996.

Stiglitz, Joseph E. "Role of Government in the Contemporary World." Paper presented to the conference sponsored by the International Monetary Fund, "Income Distribution and Sustainable Growth," Washington, DC, July 1995.

Tomkins, Cyril R. Achieving Economy, Efficiency and Effectiveness in the Public Sector. Edinburgh: Institute of Chartered Accountants of Scotland, 1978.

Weber, Max. Economy and Society. Berkeley: University of California Press, 1978 [originally published in German, 1922]. 